\title{
SEROPREVALENCE OF CHAGASIC INFECTION IN YOUNG INDIVIDUALS IN A BLOOD CENTER IN THE STATE OF SÃO PAULO, BRAZIL
}

Elaine Cristina NAVARRo(1), Renata Leme GOTO(1), Isabella Silva RICOBONI(1), José Eduardo CORRENTE(2), Rita Maria Saccomano HENRIQUES(3), Silvio Luiz NEVES(3), José Mauro ZANINI(3), Ângela Aparecida DORINI(3) \& Paulo Câmara Marques PEREIRA(1)

\begin{abstract}
SUMMARY
This study aimed at estimating the number of cases of non-negative serological reactions to Chagas disease in blood donors at the Blood Center of Botucatu, São Paulo, Brazil, from 2003 to 2010 and at relating them to their cities of origin. Five hundred and seventy-four non-negative results for Chagas disease were evaluated. Of these, 371 (64.8\%) were reagent, and 203 (35.4\%) were inconclusive. The prevalence of Chagas disease in blood donors was $0.05 \%$. There were, on average, 72 cases/year, and a prevalence of males was observed (64.8\%). Forty-three (7.49\%) individuals were 18 to 30 years old; $92(16.02 \%)$ were 31 to $40 ; 147$ (25.61\%) 41 to 50, and $292(50.87 \%)$ were older than 50 years. It was observed that $29.3 \%$ of females with reagent serology were at their fertile age (18 and 45 years). The majority of donors were originally from cities in the southwestern and central regions of São Paulo, but individuals from other states contributed with $20 \%$. The provenance of most donors was the city of Botucatu/SP, followed by the city of Taquarituba/SP. Therefore, the profile of donors at this blood center favors the occurrence of a larger number of non-negative serological reactions. Although there has been a significant reduction in the number of new cases/year for this disease, it is still a public-health problem, and results suggest the need for new epidemiological assessments in the studied region.
\end{abstract}

KEYWORDS: Chagas disease; Blood donation; Epidemiology.

\section{INTRODUCTION}

Chagas disease, also known as American Trypanosomiasis, was firstly described in 1909 by the Brazilian physician Carlos Justiniano Chagas. The disease is caused by protozoan Trypanosoma cruzi, and an incidence rate of 40 thousand new cases a year is estimated ${ }^{15}$.

According to WHO (2010), there are still 10 million infected people worldwide, especially in Latin America, with more than 25 million people in areas of transmission risk, and more than 10,000 deaths in $2008{ }^{17}$. In Brazil, there are at least three million infected individuals, and since the majority of chronic chagasic individuals have the indeterminate form of the disease (without symptoms), this figure may be even higher ${ }^{12}$.

Control of vector-borne transmission (the most frequent transmission form) was initiated in 1950 in some areas in the country and became a nationwide program in $1983^{12}$. In 2006, Brazil was certified as a free area of Chagas disease vector-borne transmission by the Pan American Health Organization (PAHO); however, that represented the temporary interruption of the disease specifically by the triatomide of the $T$. infestans species and not its eradication ${ }^{6}$. After the complete or partial interruption of vector-born transmission, blood transfusion became the main mechanism of Chagas disease acquisition in the 1980s and 1990s. As from the 1988 Constitution, new mechanisms were created in order to prevent the transmission of several diseases by blood transfusion, among which were HIV and Chagas disease. Donor remuneration was prohibited, and serological selection of blood donation candidates became mandatory ${ }^{3}$.

In 1960, it was estimated that, in São Paulo State, 6,000 individuals had received blood transfusions infected with the protozoan, and that, in Rio de Janeiro, the figure was 10,000. In the same year, WHO estimated seven million new cases per year in Latin America due to contaminated transfusions ${ }^{2}$.

In Brazil, as a result of the systematic fight against the vector and mandatory serological tests in blood therapy services, the occurrence of non-negative reactions was $7.0 \%$ in the 1970 s and changed to $0.6 \%$ in the $1990 \mathrm{~s}^{4,10}$.

According to RASSI et al. (2010), risk for acquiring Chagas disease after a single blood unit from an infected donor is less than 10-20\% and depends on various factors, including the parasitic concentration in the

(1) Department of Tropical Diseases, Botucatu School of Medicine (FMB/Unesp), Botucatu, SP, Brazil.

(2) Department of Biostatistics, Biosciences Institute (IBB/Unesp).

(3) Serology Laboratory, Botucatu School of Medicine (FMB/Unesp), Blood Center Division, Botucatu, SP, Brazil.

(4) Departamento de Doenças Tropicais e Diagnóstico por Imagem, Faculdade de Medicina de Botucatu (FMB/Unesp), Rubião Júnior, s/n, Botucatu, SP, Brasil.

Correspondence to: Elaine Cristina Navarro. E-mail: navarro@fc.unesp.br

Financial support: FAPESP no. 2010/51949-2. 


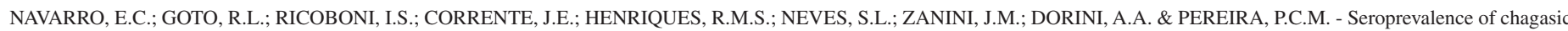
infection in young individuals in a blood center in the state of São Paulo, Brazil. Rev. Inst. Med. Trop. Sao Paulo, 55(4): 245-50, 2013.

donor's blood and the blood component to be transfused. Risk seems to be higher in platelet transfusion than in that of other components ${ }^{13}$.

The Botucatu Blood Center is responsible for receiving blood donations from a large region which comprehends the VI Regional Health Management Office VI (DRS VI). Many individuals carrying Chagas disease in its indeterminate form report as candidates for blood donation without being aware of such condition. When serological results are positive or inconclusive, these individuals are referred to the Infectious Diseases Outpatient Unit, which is responsible for confirming their serology and, if necessary, for initiating the patients' follow-up.

In view of the consideration above, this study aimed at estimating the number of cases of non-negative serological reactions to Chagas Disease in blood donors at the Botucatu Blood Center from 2003 to 2010 and at relating such donors to their cities of origin.

\section{MATERIAL AND METHODS}

This study was authorized by the Research Ethics Committee of the Botucatu School of Medicine (Document: CEP3814-2011).

It is a retrospective study in which 574 results of serological reaction to Chagas disease from the Botucatu Blood Center in São Paulo, Brazil, for the period of January 2003 to December 2010, were analyzed.

The variables investigated were obtained from the records filed at the Serology Laboratory of the Botucatu School of Medicine (Unesp) Blood Center Division.

For variable age, the donors were divided into four groups: (1) younger or equal to 30 years; (2) between 31 and 40 years; (3) between 41 and 50 years and (4) older than 50 years.

Donor type classification followed the criterion used at the Botucatu Blood Center: (1) returning donors - those who had donated blood at regular periods in the last two years; (2) irregular donors - those who had previously donated blood at the Botucatu Blood Center, but did not return at regular periods, and (3) new donors - those who were donating to the Botucatu Blood Center for the first time.

Non-negative serological reactions to Chagas disease were separated into two groups: (1) reagent and (2) inconclusive. The gray zone was established by adding or subtracting $20 \%$ cut off.

The individuals' cities of birth were considered to be their cities of origin, and those where they lived at the time of blood donation were considered to be their provenance.

The Botucatu Blood Center uses the ELISA method for diagnosing Chagas disease in blood donors; however, when a case is inconclusive, the ELISA test and/or other tests, such as indirect hemagglutination (IHA) and indirect immunofluorescence (IF) are repeated. In the analyzed period the kits used were: ELISA (enzyme linked immunoassay) - BIOELISA Cruzi $\left(\right.$ Biolab $\left.^{\circledR}\right)$ and Chagas Elisa III Test (Bioschile/ Abbott ${ }^{\circledR}$ - (Bioschile Ingenieria Genética S.A., Santiago, Chile); indirect hemagglutination - Hemacruzi (Biolab ${ }^{\circledR}$ - Diagnostica, RJ, Brazil) and Imuno-HAI
(Wama Diagnostica ${ }^{\circledR}$ ); indirect immunofluorescence - anti human IgG labeled with fluorescein isocyanate $\left(\right.$ Biolab $^{\circledR}$ ) and Imuno-COM (Wama Diagnostica $\left.^{\circledR}\right)$.

All bags serologically non-negative (reagents or inconclusive) were discarded as required by law.

The serological results of individuals with inconclusive serology were reevaluated one year and a half after the investigation with the purpose to observe whether the candidates for blood donation had undergone serological screening for serology confirmation.

As to the statistical analysis, at first, descriptive analysis, with frequencies and percentages, was performed for qualitative variables, and with means and standard deviation for quantitative variables. The associations between qualitative variables were made by using the chisquare test as well as differences between proportions.

In order to evaluate reduction in the number of cases in seven years, a generalized linear model with binomial distribution and logistic linkage was fitted though the GENMOD procedure of the software SAS for Windows, v.9.2, followed by the multiple-comparison test.

The level of significance considered was $5 \%$ or its corresponding $p$-value. All the analyses were performed by the SAS software for Windows, v.9.2.

\section{RESULTS}

In the studied period, 108,747 blood bags were collected, of which $37 \%$ were from new donors, $23 \%$ from irregular donors and $40 \%$ from returning donors.

Serological screening of $91.1 \%$ of donors was performed only by the ELISA test, $0.52 \%$ by ELISA and Hemagglutination (IHA), $8.03 \%$ by ELISA and Indirect Immunofluorescence (IF) and $0.35 \%$ by ELISA, IHA and IF.

Five hundred and seventy-four non-negative serological reactions to Chagas disease were analyzed. Three hundred and seventy-one reactions were reagent (64.6\%) and 203 were inconclusive (35.4\%).

As regards occurrence, on average, approximately 72 non-negative diagnoses for Chagas disease were observed per year, and also on average, 47 of them were reagent. By fitting the binomial model and considering the proportion of cases per year followed by multiple comparisons between the years, significant reduction $(p<0.05)$ was found in the proportion of new cases as from 2005 (Table 1).

The evaluation of non-negative donors according to gender showed that 202 were females (35.2\%) and 372 were males (64.8\%), which is a similar rate to the general proportion of blood donors at the Botucatu Blood Center. There was positive association between reagent serology for Chagas disease and males $(p<0.0001)$, but there was no positive association between inconclusive serology and gender $(p=0.074)$.

The classification of donors into four age ranges showed a positive correlation between age increase and the percentage of non-negative 


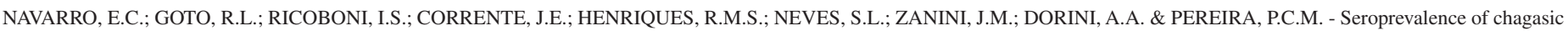
infection in young individuals in a blood center in the state of São Paulo, Brazil. Rev. Inst. Med. Trop. Sao Paulo, 55(4): 245-50, 2013.

serological reactions in the two groups (reagent and inconclusive), as observed in Table 2.

Table 1

Association between bags rejected by non-negative serology between the period 2003 to 2010

\begin{tabular}{lcccc}
\hline Year & $\begin{array}{c}\text { Total } \\
\text { donations } *\end{array}$ & $\begin{array}{c}\text { Bags } \\
\text { Rejected** }\end{array}$ & Reagent*** & $\begin{array}{c}\text { Inconclu- } \\
\text { sives**** }\end{array}$ \\
\cline { 3 - 5 } 2003 & 12294 & $119(0.97)$ & $79(0.64)$ & $40(0.32)$ \\
2004 & 12048 & $98(0.81)$ & $67(0.56)$ & $31(0.26)$ \\
2005 & 13137 & $89(0.68)$ & $69(0.52)$ & $20(0.15)$ \\
2006 & 12791 & $77(0.60)$ & $36(0.28)$ & $41(0.32)$ \\
2007 & 13387 & $61(0.45)$ & $30(0.22)$ & $31(0.23)$ \\
2008 & 14540 & $42(0.29)$ & $27(0.18)$ & $15(0.10)$ \\
2009 & 14927 & $39(0.26)$ & $30(0.20)$ & $09(0.06)$ \\
2010 & 15623 & $49(0.31)$ & $33(0.21)$ & $16(0.10)$ \\
\hline Total & 108747 & $574(0.53)$ & $371(0.34)$ & $203(0.19)$ \\
\hline
\end{tabular}

* Number of units of blood collected between January 1 and December 31 of each year; ** Bags rejected by non-negative serology for Chagas disease (reagent or inconclusive); *** Number of bags rejected due to reagent serology for Chagas disease in individuals of both sex; **** Number of bags rejected due to inconclusive serology for Chagas disease in individuals of both sexes.

Table 2

Description of serologic reactions non-negative (reagents or inconclusive) for Chagas disease found in relation to age

\begin{tabular}{lccccc}
\hline \multicolumn{5}{c}{ Age range } & \\
\cline { 2 - 5 } & $\begin{array}{c}18 \text { to } 30 \\
\text { years }\end{array}$ & $\begin{array}{c}31 \text { to } 40 \\
\text { years }\end{array}$ & $\begin{array}{c}41 \text { to } 50 \\
\text { years }\end{array}$ & $\begin{array}{c}>50 \\
\text { years }\end{array}$ & p-value* \\
\hline Inconclu- & 23 & 39 & 49 & 92 & 0.0159 \\
sive & $(4.00 \%)$ & $(6.79 \%)$ & $(8.54 \%)$ & $(16.03 \%)$ & \\
Reagent & 20 & 53 & 98 & 200 & \\
& $(3.49 \%)$ & $(9.23 \%)$ & $(17.07 \%)$ & $(34.84 \%)$ & \\
\hline Total & 43 & 92 & 147 & 292 & \\
& $(7.49 \%)$ & $(16.02 \%)$ & $(25.61 \%)$ & $(50.87 \%)$ & \\
\hline
\end{tabular}

*-significant association between age range and serology.

Ninety-two women with positive serology were identified during the study period, representing $0.26 \%$ of all donations of females (Table 3 ). Among women who had positive serology for Chagas disease, $29.3 \%$ were of a fertile age (between 18 and 45 years).

The donors who sought the Botucatu Blood Center predominantly dwelt in urban areas (89\%). The donors' origin was heterogeneous, and $43 \%$ were born in cities in São Paulo State, such as Taquarituba, Avaré, Botucatu, Itaí, Itaporanga, Taguaí, Paranapanema and Fartura; 37\% in other cities of São Paulo State and $20 \%$ in other states, such as Paraná, Minas Gerais, Bahia, Pernambuco, Goiás, Sergipe, Paraíba, Rio Grande do Norte, Mato Grosso, Pará and Alagoas (Table 4). All donors came from cities in São Paulo State, and the majority came from the southwestern and central regions (Table 5).

Table 3

Association between number of donations seropositive for Chagas disease women and women in fertile age ( 18 to 45 years)

\begin{tabular}{lcccc}
\hline \multirow{2}{*}{ Year } & \multirow{2}{*}{$\begin{array}{c}\text { Total } \\
\text { donations }\end{array}$} & $\begin{array}{c}\text { Donations } \\
\text { Women }\end{array}$ & $\begin{array}{c}\text { Reagents } \\
\text { women }\end{array}$ & $\begin{array}{c}\text { Women in } \\
\text { fertile age* }\end{array}$ \\
\cline { 4 - 5 } 2003 & 12294 & 3385 & $16(0.47)$ & $8(0.24)$ \\
2004 & 12048 & 3674 & $15(0.41)$ & $6(0.16)$ \\
2005 & 13137 & 4133 & $17(0.41)$ & $1(0.02)$ \\
2006 & 12791 & 4104 & $12(0.30)$ & $1(0.02)$ \\
2007 & 13387 & 4376 & $11(0.25)$ & $3(0.07)$ \\
2008 & 14540 & 4704 & $3(0.06)$ & $0(0.00)$ \\
2009 & 14927 & 5157 & $11(0.21)$ & $7(0.13)$ \\
2010 & 15623 & 5532 & $7(0.13)$ & $1(0.02)$ \\
\hline Total & 108747 & 35065 & $92(0.26)$ & $27(0.08)$ \\
\hline
\end{tabular}

* Women with serology reagent in fertile age (18 to 45 years).

Table 4

Place of origin of blood donors with non-negative serology for Chagas disease

\begin{tabular}{lcc}
\hline Origin & Number & Percentage \\
\hline Taquarituba & 58 & 10.1 \\
Avaré & 35 & 6.1 \\
Botucatu & 34 & 5.9 \\
Itaí & 31 & 5.4 \\
Itaporanga & 25 & 4.3 \\
Taguai & 22 & 3.8 \\
Paranapanema & 19 & 3.3 \\
Fartura & 18 & 3.1 \\
Other cities in São Paulo State & 209 & 36.4 \\
Cities from other states & 115 & 20.0 \\
Unknown origin & 8 & 1.4 \\
Total & 574 & 100 \\
\hline
\end{tabular}

Table 5

Provenance of blood donors with non-negative serology for Chagas disease

\begin{tabular}{lcc}
\hline Provenance & Number & Percentage \\
\hline Botucatu & 93 & 16.2 \\
Taquarituba & 56 & 9.7 \\
Itaporanga & 35 & 6.1 \\
Paranapanema & 35 & 6.1 \\
Itaí & 32 & 5.6 \\
Avaré & 31 & 5.4 \\
Itatinga & 20 & 3.5 \\
Fartura & 19 & 3.3 \\
Other cities in São Paulo State & 253 & 44.1 \\
\hline Total & 574 & 100 \\
\hline
\end{tabular}




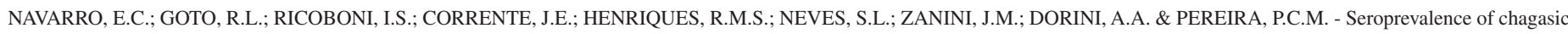
infection in young individuals in a blood center in the state of São Paulo, Brazil. Rev. Inst. Med. Trop. Sao Paulo, 55(4): 245-50, 2013.

The review of inconclusive serological results for Chagas disease after 18 months showed non-reagent results for 27 individuals, of whom two were up to 30 years old; three from 31 to 40 years old, seven from 41 to 50 years old and 15 older than 50 years. Serology was confirmed as reagent in 14 individuals, of whom two were 41 to 50 years old, and 12 were older than 50 years.

\section{DISCUSSION}

The Botucatu Blood Center serves a region with 1,646,604 inhabitants that comprehends the VI Regional Health Management Office VI (DRS VI), Bauru. Many cities in this region were considered to be endemic areas for disease until the late 1980s.

Chagas disease has drastically decreased in Brazil due to various effective measures adopted by the government in order to fight the vector as well as to more strict blood transfusion procedures in which the donated blood is analyzed by increasingly more sensitive and specific immunologic methods.

Since 2004, by following the RDC 153 recommendation from Anvisa, the Blood Center has used only the ELISA test, which is a high-sensitivity method, for the serological screening of blood donors. The indirect Hemagglutination and Immunofluorescence tests have been used only for confirmation of inconclusive diagnoses. All blood banks use the same tests and the same classification criteria (values above $20 \%$ of the reagents and are cut off range of $20 \%$ below or above the cut off are indeterminate).

The percentage of inconclusive reactions $(35.4 \%)$ at the Botucatu Blood Center was lower than that found at the Uberaba Regional Blood Center (53\% of the non-negative reactions) and at the Pernambuco Blood Center $(60.30 \%)^{9,10}$. Co-infection with other diseases may lead to crossreactions as well as to the low specificity of the tests used.

The percentage of bags with non-negative serology for Chagas disease was $0.5 \%$, which was a similar value to that found by LUNARDELLI et al. $(2007)^{8}$ at São Lucas Hospital of the Pontifical University of Rio Grande do Sul and higher than the national average $(0.2 \%)^{11}$. It was also lower than that found by SILVA \& SILVA (2010) at Hemominas, Patos de Minas (MG) Regional Office, where the estimated prevalence was $1.2 \%{ }^{14}$. A study conducted by MELO et al. $(2009)^{9}$ at the Pernambuco Blood Center (HEMOPE) from 2002 to 2007 on the non-negative serological reactions to Chagas disease found a prevalence rate of $0.17 \%$ of the total number of donations, with an annual mean of discarded bags of 127.5 this value higher than that found at the Blood Center of Botucatu (72 units/year). It is noteworthy that there are, on average, 46 new confirmed cases per year (reagent serology) and other 25 suspected cases (inconclusive reactions). This requires that the donors be again called for serological confirmation. Therefore, the large number of new diagnoses confirmed for the disease per year is extremely worrisome, and this situation deserves attention from publichealth authorities. In a study on blood donors at the Araraquara Blood Center São Paulo, FERREIRA-FILHO et al. $(2011)^{5}$ found $0.04 \%$ of non-negative reactions, but the high rate of tests with inconclusive results suggests little specificity for the tests used by the service, contrarily to the findings at the Botucatu Blood Center.
The profile of donors in the present study predominantly comprised males older than 50 years. This profile was different from that found by SOBREIRA et al. $(2001)^{16}$ at the Iguatu Blood Center (CE), where most donors were 18 to 30 years old. The prevalence of donors older than 50 years in a historically endemic area region for Chagas disease is a reason for alert to the blood center, considering that the majority of contaminated individuals were in that age range, as control campaigns became actually significant in the 1970s.

The positive association found between reagent serology and males may be related to the large number of individuals who work in rural areas and are more exposed to the contact with triatomines.

According to the proportions test, there were a large number of individuals who were 30 years old or younger (7.49\%); however, more than $70 \%$ of the individuals were older than 40 years, which confirms that government campaigns for Chagas disease in the country were successful.

The percentage of seropositive women in relation to the total donor females, although small $(0.08 \%)$, was significant from the point of view of public health. Considering that in 108,747 donations (both sexes) 371 reagents were found, it can be estimated that in 1,640,606 inhabitants of this region there is an average of 5597 inhabitants with positive serology and, if this estimate were performed for women of fertile age, there would be 407 seropositive women in this region and as most do not donate blood and do not take this for serological routine pathology and have no symptoms (indeterminate form), they are unaware of their condition.

The high percentage of individuals up to 30 years old $(7.49 \%)$ and the percentage of women at a fertile age $(29.3 \%)$ were the most worrisome data found in this study population, since these individuals usually show the indeterminate form of Chagas disease, and its diagnosis is almost accidental as, for instance, when they voluntarily report to the center for blood donation. Although the cities in DRS VI are in an endemic area, serological screening for Chagas disease is not mandatory in prenatal tests, and its vertical transmission may occur. Such form of transmission could explain the percentage of individuals up to 30 years old who showed reagent serology for the disease (3.49\%). Another possible explanation is the invasion of secondary triatomine species, such as $P$. megistus and T. sordida in areas that were previously occupied by $T$. infestans, which was virtually eliminated during the control campaigns against disease.

In an epidemiological study conducted by CARVALHO et al. $(2011)^{1}$ from 1976 to 1980 on 31,468 individuals from cities in the micro-region of Campos de Itapetininga and in the micro-region of the western hillside of Mantiqueira found that most carriers of Chagas disease were older than 40 years; however, there were still $4.5 \%$ of individuals who were younger than 20 years and a considerable percentage of seropositivity in women at a fertile age, between 15 and 49 years. It is noteworthy that these cities are located within the region covered by the present study.

The candidates for blood donation who seek the Botucatu Blood Center predominantly live in urban areas (89\%). This is a reality in almost all blood centers in the country, since, in the 1950s and 1960s, large numbers of people left rural areas and settled in the outskirts of cities, where they were frequently exposed to precarious housing conditions 
NAVARRO, E.C.; GOTO, R.L.; RICOBONI, I.S.; CORRENTE, J.E.; HENRIQUES, R.M.S.; NEVES, S.L.; ZANINI, J.M.; DORINI, A.A. \& PEREIRA, P.C.M. - Seroprevalence of chagasic infection in young individuals in a blood center in the state of São Paulo, Brazil. Rev. Inst. Med. Trop. Sao Paulo, 55(4): 245-50, 2013.

which enabled contact with disease vectors, as for instance, the triatomine popularly known as "barbeiro".

The city of Taquarituba, located in the southwestern part of São Paulo State, was the main city of origin of donors with non-negative serology, and in this group of individuals, the reagent result prevailed (69\%), thus confirming the results obtained by GODOY \& MEIRA $(2007)^{7}$, who performed serological tests in individuals with a positive xenodiagnosis for Chagas disease. In that city, it was found that the mean age of candidates for donation was 50.2 years (SD of 9.7 years) and that there were seven women at a fertile age (up to 45 years), thus showing risk for vertical transmission. Other cities in São Paulo State also greatly contributed to the high frequency of non-negative results, such as the cities of Itaí, Itaporanga, Taguaí and Coronel Macedo, which showed large numbers of chagasic individuals from the 1950s to the 1980s. A large number of individuals from other states, such as Paraná, Minas Gerais, Pernambuco, Paraíba, Sergipe, Bahia, Alagoas, Mato Grosso, Pará and Goiás were also found (Table 4).

The provenance of donation candidates was less heterogeneous, and the city of Botucatu contributed with the largest number of donors (Table 5). It is noteworthy that the cities considered to be endemic until the 1980s and the 1990s contributed with a large number of donations, thus increasing the chance for finding donors with non-negative serology.

The review of inconclusive serological tests showed that the majority (79.31\%) of individuals did not return to the blood center to confirm the serological test. Of those who did return to confirm their results, it was observed that more than half were reagent to Chagas disease and that there was a positive association between confirmatory reagent serology and older age, thus confirming official data from the Ministry of Health and from various authors mentioned above, who reported that Chagas disease was partly controlled, considering that the highest prevalence occurs in individuals older than 50 years.

\section{CONCLUSION}

Chagas disease is still an important public health problem and, although a significant reduction in the number of cases per year has been observed, it must be a priority in health care services and better investigated in relation to its actual occurrence.

Blood donors at the Botucatu Blood Center are older than 50 years, males with a predominance of the indeterminate form and originally from historically endemic regions for Chagas disease in São Paulo State, such as the cities of Taquarituba, Avaré and Itaporanga. With this in mind, it is more likely that the individuals acquired the parasite in childhood, when eradication programs for Chagas disease were still in their early phases.

There is a notably large number of new diagnoses for Chagas disease per year that must be better investigated, however, the large number of individuals between 18 and 30 years old with non-negative serology for Chagas disease (20 confirmed and 21 suspected cases) is noteworthy, as well as the number of women in fertile age with positive serology.

New epidemiological studies must be conducted in these donors' cities of origin in order to consider the possibility of vertical transmission and vector transmission by secondary species.

\section{RESUMO}

\section{Soroprevalência da infecção chagásica em indivíduos jovens em Hemocentro no Estado de São Paulo, Brasil}

Este estudo teve como objetivo estimar o número de casos de reações sorológicas não-negativas para doença de Chagas em doadores de sangue do Hemocentro de Botucatu, São Paulo - Brasil de 2003 a 2010 e, relaciona-las com as suas cidades de origem. Quinhentos e setenta e quatro reações sorológicas não-negativas para doença de Chagas foram avaliados. Destes, 371 eram reagentes (64,8\%), e 203 inconclusivos $(35,4 \%)$. A prevalência da doença de Chagas nos doadores de sangue foi de $0,05 \%$. Houve, em média, 72 casos/ano, e uma prevalência do sexo masculino foi observada $(64,8 \%)$. Quarenta e três indivíduos $(7,49 \%)$ tinham entre 18 e 30 anos, $92(16,02 \%)$ de 31 a 40; $147(25,61 \%) 41$ a 50 , e $292(50,87 \%)$ tinham mais de 50 anos. Observou-se que $29.3 \%$ das mulheres com sorologia reagente estavam em idade fértil (18 e 45 anos). A maioria dos doadores eram naturais de cidades das regiões sudoeste e central da cidade de São Paulo, mas os indivíduos de outros estados contribuíram com $20 \%$. A procedência da maioria dos doadores era a cidade de Botucatu/SP, seguido pela cidade de Taquarituba/SP. Portanto, o perfil de doadores de sangue neste hemocentro favorece a ocorrência de um número maior de reações sorológicas não-negativas. Embora tenha havido uma redução significativa no número de casos novos/ano para esta doença, ainda é um problema de saúde pública, e os resultados sugerem a necessidade de novas avaliações epidemiológicas na região estudada.

\section{REFERENCES}

1. Carvalho, ME, Silva, RA, Wanderley, DMV, Barata, JMS. Programa de controle da doença de Chagas no Estado de São Paulo: aspectos soroepidemiológicos em microrregiões geográficas homogêneas. Rev Soc Bras Med Trop. 2011;44:110-2.

2. Coura, JR, Vinhãs, PA. Chagas disease: a new worldwide challenge. Nature 2010;465(7301):6-7

3. DIAS JCP. Doença de Chagas e transfusão de sangue no Brasil: vigilância e desafios Rev Bras Hematol Hemoter. 2006;28:83-4.

4. Dias JCP. Elimination of Chagas disease transmission: perspectives. Mem Inst Oswaldo Cruz. 2009;104(Suppl 1):41-5.

5. Ferreira-Filho JCR, Costa PI, Buainain A, Rosa JA. Soropositividade para doença de Chagas entre doadores de sangue em Araraquara, Estado de São Paulo, no período de 2004 a 2008. Rev Soc Bras Med Trop. 2011;44:110-2.

6. Fitarelli DB, Horn JF. Descarte de bolsas de sangue devido à reatividade para doença de Chagas em um laboratório de triagem sorológica de doadores em Porto Alegre-RS Rev Bras Hematol Hemoter. 2009;31:310-4.

7. Godoy I, Meira DA. Soroprevalência da infecção chagásica em moradores de municípios da região de Botucatu, Estado de São Paulo. Rev Soc Bras Med Trop. 2007;40:516-20.

8. Lunardelli A, Borges FP, Mello KF, Zeferino ASA. Soroprevalência da doença de Chagas em candidatos a doadores de sangue. Rev Bras Anal Clin. 2007;39:139-41.

9. Melo AS, Lorena VMB, Moraes AB, Pinto BA, Leão SC, Soares AKA, et al. Prevalência de infecção chagásica em doadores de sangue no estado de Pernambuco, Brasil. Rev Bras Hematol Hemoter. 2009;31:69-73.

10. Moraes-Souza H, Martins PRJ, Pereira GA, Ferreira-Silva M, Abud MB. Perfil sorológico para a doença de Chagas dos doadores de sangue do Hemocentro Regional de Uberaba. Rev Bras Hematol Hemoter. 2006;28:110-4 
NAVARRO, E.C.; GOTO, R.L.; RICOBONI, I.S.; CORRENTE, J.E.; HENRIQUES, R.M.S.; NEVES, S.L.; ZANINI, J.M.; DORINI, A.A. \& PEREIRA, P.C.M. - Seroprevalence of chagasic infection in young individuals in a blood center in the state of São Paulo, Brazil. Rev. Inst. Med. Trop. Sao Paulo, 55(4): 245-50, 2013.

11. Moraes-Souza H, Ferreira-Silva MM. O controle da transmissão transfusional. Rev Soc Bras Med Trop. 2011;44(Supl 2):64-7.

12. Petherick A. Country by country. Nature. 2010;465(7301):S10-1.

13. Rassi A Jr, Rassi A, Marin-Neto JA. Chagas disease. Lancet. 2010;375(9723):1388-402.

14. Silva LP, Silva RMG. Inquérito soroepidemiológico sobre a infecção chagásica em doadores de sangue na região do Alto Paranaíba, Minas Gerais. Biosci J. 2010;26: 824-7.

15. Soares LMB. Eliminação da transmissão e morbidade da infecção chagásica crônica em pacientes autóctones da microrregião do rio negro, Estado do Amazonas (1997-2008). [dissertação]. Rio de Janeiro: Instituto Osvaldo Cruz; 2009.
16. Sobreira ACM, Gomes FVBAF, Silva MAM, Oliveira MF. Prevalência de infecção chagásica em doadores de sangue do Hemocentro Regional de Iguatu, CE. Rev Soc Bras Med Trop. 2001;34:193-6.

17. WHO. [database on the Internet]. Chagas disease (American trypanosomiasis). Geneve; 2010. [cited 2011 Jan 02]. Available from: http://www.who.int/mediacentre/factsheets/ fs $340 /$ en/

Received: 09 Decembeer 2012

Accepted: 28 January 2013 